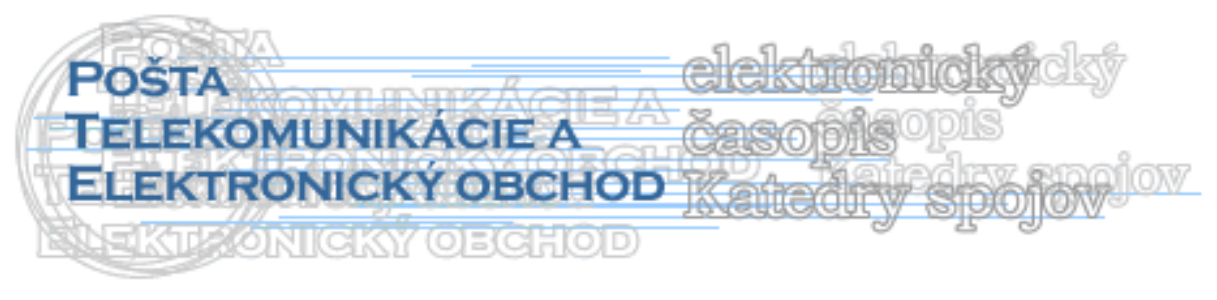

\title{
ŠIROKOPÁSMOVÝ PRÍSTUP V SLOVENSKEJ REPUBLIKE - TEORETICKÉ PREDPOKLADY
}

\author{
Juraj Fabuš*
}

\section{Úvod}

Séria článkov vzniká za účelom vysvetlenia a objasnenia pojmu širokopásmový prístup, hlavnou témou je vysvetlenie pojmu širokopásmový prístup, zhodnotenie stavu širokopásmového prístupu v SR, taktiež je popísaná infraštruktúra širokopásmového prístupu.

Zverejnenie práce je $\mathrm{z}$ dôvodu obšírnosti problematiky rozdelené do viacerých článkov, ktoré budú postupne publikované $\mathrm{v}$ tomto elektronickom časopise. V d'alších častiach bude spracované porovnanie stavu širokopásmového prístupu v Slovenskej republike s krajinami EÚ, nasledovat' bude návrh opatrení, ktoré napomôžu k rozšíreniu využívania širokopásmového prístupu pre všetkých obyvatel'ov SR.

Ciel'om je zvýšit' povedomie o širokopásmovom prístupe, zvýšit' záujem o jeho využívanie, čo bude mat' konečný vplyv aj na postavenie Slovenska v rámci EÚ, kde sme medzi členskými krajinami na poslednom mieste vo využívaní širokopásmového prístupu. Články sú určené všetkým, ktorí širokopásmové služby už využívajú, ale aj pre tých, ktorí sa s nimi ešte len zoznamujú.

\section{Základné pojmy}

Vo všeobecnosti je širokopásmový prístup (broadband) taký druh prístupu k poskytovaným zdrojom a službám, ktorý koncových užívatel'ov neobmedzuje v druhu, obsahu, rozsahu a kvalite požadovanej služby a je dostupný trvalo, 24 hodín denne, 7 dní v týždni. V nasledujúcom texte sú vysvetlené dôležité pojmy, ktoré sa vyskytujú v skúmanej oblasti.

Elektronické komunikácie [1] zabezpečujú výmenu alebo prenos informácií medzi konečným počtom užívatel'ov uskutočňovaných po elektronických komunikačných siet’ach. Elektronické komunikácie nezahŕňajú informácie prenášané ako súčast' televízneho a rozhlasového vysielania pre verejnost' prostredníctvom elektronickej komunikačnej siete okrem informácií, ktoré sa týkajú identifikovatel'ného užívatel’a prijímajúceho informácie.

Elektronická komunikačná siet’ (d’alej len „siet““) je funkčne prepojená sústava prenosových systémov a v prípade potreby prepájacích a smerovacích zariadení, ako aj iných

\footnotetext{
${ }^{*}$ Ing. Juraj Fabuš, PhD., Žilinská univerzita v Žiline, Fakulta prevádzky a ekonomiky dopravy a spojov, Katedra Spojov, Univerzitná 1, 01026 Žilina, Slovenská republika, tel.: +421 908171 890, E-mail:

juraj.fabus@fpedas.uniza.sk
} 
prostriedkov, ktoré umožňujú prenos signálu po vedení, rádiovými, optickými alebo inými elektromagnetickými prostriedkami, vrátane družicových sietí, pevných sietí s prepájaním okruhov a s prepájaním paketov vrátane internetu a mobilných pozemských sietí, sietí pre rozvod elektrickej energie $\mathrm{v}$ rozsahu, $\mathrm{v}$ ktorom sa používajú na prenos signálov, sietí pre rozhlasové a televízne vysielanie a káblových distribučných systémov, bez ohl'adu na druh prenášaných informácií.

Verejná siet' sa úplne alebo prevažne používa na poskytovanie verejne dostupných elektronických komunikačných služieb.

Elektronická komunikačná služba (d’alej len služba) je služba obvykle poskytovaná za úhradu, ktorá spočíva úplne alebo prevažne $\mathrm{v}$ prenose signálov $\mathrm{v}$ siet'ach, vrátane telekomunikačných služieb a prenosových služieb $\mathrm{v}$ siet’ach používaných na rozhlasové a televízne vysielanie. Služba nie je poskytovanie obsahu ani redakčný dohl'ad nad obsahom prenášaným s využitím elektronických komunikačných sietí a služieb.

Prístup je sprístupnenie zariadení, elektronických komunikačných služieb alebo zariadení a elektronických komunikačných služieb inému podniku na poskytovanie elektronických komunikačných služieb, najmä prístup k:

- účastníckemu vedeniu a $\mathrm{k}$ prostriedkom a službám potrebným na poskytovanie služieb prostredníctvom účastníckeho vedenia,

- pevným siet’am a mobilným siet’am, najmä službám roamingu,

- zariadeniam na prevod čísel alebo k systémom ponúkajúcim ekvivalentnú funkciu,

- príslušným softvérovým systémom vrátane prevádzkových podporných systémov,

- infraštruktúre vrátane stavieb, priestorov a častí vedení sietí,

- systémom podmieneného prístupu na služby digitálnej televízie,

- službám virtuálnych sietí.

Prepojenie je fyzické a logické spojenie verejných sietí používaných tým istým alebo iným podnikom umožňujúce uživatel'om siete jedného podniku komunikovat' s užívatel'om toho istého alebo iného podniku alebo umožňuje prístup k elektronickým komunikačným službám poskytovaných iným podnikom. Tieto služby môže poskytovat podnik alebo tretia osoba, ktorí majú prístup $\mathrm{k}$ verejnej sieti. Prepojenie je osobitný druh prístupu medzi poskytovatel'mi verejných sietí.

\section{Širokopásmový prístup}

Broadband siete a služby sú také, ktoré zabezpečia v každom čase neprerušovaný a rýchly prístup občanov $\mathrm{k}$ informáciám a telekomunikačným systémom. Pretože prostredie telekomunikácií je dynamické a neustále sa mení, nie je možné broadband definovat' pomocou konkrétnych rýchlostí a technológií.[2]

Základnými parametrami širokopásmového prístupu sú nominálna prenosová rýchlost' a skutočne dosahovaná, tzv. efektívna prenosová rýchlost' pripojenia koncových užívatel'ov. Je dôležité, aby sa v praktickej prevádzke, ktorá využíva reálne prenosové kapacity chrbticových prepojení uzlov, obe prenosové rýchlosti významne odlišovali. 
Pôvodná definícia stanovená odporúčaniami ITU-T označuje širokopásmový prístup za prístup s prenosom rýchlejším ako primárny prístup ISDN, t.j. väčší ako $2 \mathrm{Mbit} / \mathrm{s}$. Vývoj v poskytovaní širokopásmových služieb ale ukázal, že kritéria posudzovania pre širokopásmový prístup tiež podliehajú vývoju.

V správe o vývoji poskytovania širokopásmových služieb v krajinách OECD autori za kritérium širokopásmového prístupu označili rýchlost' prenosu $256 \mathrm{kbit} / \mathrm{s}$., pretože v prístupe k internetu umožňuje prehliadanie internetových stránok rýchlost'ou zodpovedajúcou bežnému listovaniu v knihe. Aj ITU-T uznáva $256 \mathrm{kbit} / \mathrm{s}$ ako vo všeobecnosti prijatel'nú dolnú hranicu rýchlosti širokopásmového prístupu.

V podmienkach Slovenskej republiky je možné definovat' základné kritéria širokopásmového prístupu nasledovne:

- trvalý, nepretržitý prístup,

- rýchlost' prenosu k užívatel’ovi väčší alebo rovný 256 kbit/s (zostupný smerdownstream),

- rýchlost' prenosu od užívatel’a väčší alebo rovný 64 kbit/s, (vzostupný smerupstream).[3]

Podl'a definície CCITT sa za širokopásmovú siet' resp. službu považuje siet' resp. služba, ktorá umožňuje prenosovú rýchlost' väčšiu ako je primárny prístup - teda poskytnutie prístupu účastníka pri prenosových rýchlostiach nad $2 \mathrm{Mb} / \mathrm{s}$. sú najmä :

Základné charakteristiky širokopásmových sietí poskytujúcich širokopásmové služby

- Široký rozsah ponúkaných služieb,

- multimediálny charakter ponúkaných služieb,

- integrovaný prístup t.j. prístup cez rozhranie (gateway) jednej siete k všetkým službám vrátane úzkopásmových.[3]

Z hl'adiska požadovaných parametrov pre prenos informácií v širokopásmových službách sa sledujú rôzne znaky, základné parametre sú:

- maximálna prenosová rýchlost' potrebná na prenos užívatel'skej informácie (Peak rate),

- pomer maximálnej prenosovej rýchlosti k priemernej prenosovej rýchlosti (Burstiness),

- parametre charakterizujúce kvalitu poskytovanej služby (QoS- Quality of Service).

\section{Kategorizácia služieb}

Klasifikovat' širokopásmové služby možno z viacerých hl'adísk zohl'adňujúcich určité špecifiká služieb. Širokopásmové služby možno rozdelit' na:

- interaktívne (interactive services),

- neinteraktívne (noninteractive services).

Z iného hl'adiska možno širokopásmové služby rozdelit' na:

- služby pracujúce v reálnom čase (real-time services),

- služby nepracujúce v reálnom čase (non real-time services), 
teda:

- hlasové služby,

- video služby,

- dátové služby.

ITU člení širokopásmové služby do štyroch kategórií, sú to:

- konverzačné služby (Conversational services),

- vyhl'adávacie služby (Retrieval services),

- služby na odovzdávanie správ (Messaging services),

- distributívne služby (Distribution services).[3]

Konverzačné služby - ide o služby vytvárajúce prostriedky na komunikáciu medzi užívatel'mi. Tok informácií môže byt' aj jednosmerný aj obojsmerný, obojsmerný môže byt' symetrický alebo nesymetrický.

Prenos dát v širokopásmových konverzačných službách zahŕňa najmä tieto oblasti:

- prepojovanie sietí LAN resp. MAN a tiež systémov CAD/CAM,

- prenos súborov s vel'kým objemom dát pri prepojovaní superpočítačov,

- riadenie procesov $\mathrm{v}$ reálnom čase, ktoré sa označuje „rýchla teleakcia“ a zahrňuje rýchly zber dát $\mathrm{z}$ rôznych zariadení, senzorov a ich analýzu $\mathrm{v}$ reálnom čase.

Vyhl'adávacie služby - tieto služby umožňujú užívatel'ovi možnost' vyhl'adávat' resp. vyberat' informácie z informačných centier, resp. databáz podl’a jeho požiadavky. Najčastejšie ide práve o tieto typy informácií:

- text,

- dáta,

- grafika,

- zvuk,

- statické obrazy.

Služby na odovzdávanie správ - umožňujú komunikáciu medzi užívatel’mi pomocou pamät'ovej jednotky, komunikácia neprebieha v reálnom čase. Každá správa je uložená v elektronickej poštovej schránke.

Distributívne služby - sú charakteristické tým, že predstavujú prenos informácie k vel'kému počtu užívatel’ov najčastejšie z centrálneho zdroja. Šírená informácia má multimediálny charakter (dynamický obraz, zvuk, text, dáta, grafika, video).

\section{Význam a výhody širokopásmového prístupu}

Širokopásmový prístup umožňuje bohatšiu komunikáciu medzi l’ud'mi. Kombináciou hlasu, obrázkov, videa a textu vzniknú plnohodnotné multimediálne služby, ktoré možno využit' na skvalitnenie vzdelávania, obchodnej komunikácie, súkromných a osobných rozhovorov. V súčasnosti je širokopásmový prístup možný nielen v prípade komunikácie cez drôtové vedenie, ale taktiež aj pomocou bezdrôtového dátového prenosu, kde je možnost' poskytovat' triple play pre hlas, dáta aj video priamo do mobilného telefónu zákazníka. 
Dopyt po širokopásmovom prístupe narastá. Viac ako 250 miliónov účastníkov má širokopásmové pripojenie a prognózy uvádzajú, že do roku 2009 sa počet takýchto účastníkov takmer zdvojnásobí na 400 miliónov. Napríklad spoločnost' Ericsson predpokladá, že do roku 2011 sa bude blížit' počet širokopásmových pevných a mobilných pripojení k číslu 1,5 miliardy. Aj vlády podnecujú expanziu využívania širokopásmového prístupu a mnohé budú sponzorovat' nové iniciatívy, čím sa podporí ich d'alšie rozšírenie za účelom zvýšenia národnej produktivity a realizácie strategických výhod.

V súčasnosti sa možnosti využitia širokopásmového prístupu iba začínajú objavovat', rovnako ako ich vel'mi významné dosahy na celú spoločnost', ako napríklad možnost' práce na dial'ku (homeworking, teleworking), ktorá môže ovplyvnit' riešenie otázok zamestnanosti, dopravy aj životného prostredia.

Ďalším príkladom je elektronické vzdelávanie (e-learning), ktoré ponúka alternatívu k súčasnému spôsobu vzdelávania (fyzické dochádzanie do vzdelávacích inštitúcií v dobe, ktoré stanovujú tieto inštitúcie) a robí ho nezávislým od času aj priestoru, v ktorom sa záujemca o vzdelanie nachádza, s možnost'ou prispôsobit' tempo individuálnym možnostiam a potrebám. Taktiež širokopásmový prístup poskytuje prístup k verejným službám ako elektronická verejná správa (e-government), elektronické zdravotníctvo (e-health), elektronické podnikanie (e-business), elektronické obchodovanie (e-commerce), a iné.

Širokopásmový prístup umožňuje aj:

- Pracovat's internetom, celkom novým spôsobom, ktorý by inak nebol možný.

- Jednoduchšie a rýchlejšie vyhl'adávanie informácií.

- Efektívnejšie riadenie podnikov, hlavne malých a stredných, čo má za následok zvýšenie ich výkonnosti a následne konkurencieschopnosti.

- Zjednodušenie vzájomného kontaktu medzi l'ud'mi, ale aj podnikmi, obchodnými spoločnost’ami, verejnou správou a inými organizáciami.

- Zvýšenie kvality života obyvatel'ov hlavne na vidieckych a odlahlých oblastiach, vrátane podpory rozvoja odlahlých oblastí formou stimulácie cestovania a turistík.

- Podpora celoživotného vzdelávania bez geografických a sociálnych prekážok.

Širokopásmový prístup vytvára nové možnosti:

- na trhu práce, napríklad možnost' práce $\mathrm{z}$ domu, vyhl'adávanie nových pracovných miest a iné,

- celoživotného vzdelávania bez geografických a sociálnych prekážok,

- zábavy a kultúrneho vyžitia.

\section{Záver}

Spoločným charakteristickým rysom rozvoja poskytovania širokopásmových služieb je mimoriadna pozornost', aká sa práve tejto téme venuje všade vo svete. Súčasný význam širokopásmových služieb pre rozvoj svetovej ekonomiky sa prirovnáva historickému významu niekdajšej elektrifikácie.

Význam broadband sietí pre rozvoj štátu je potvrdený intenzívnymi aktivitami mnohých krajín, ktoré si realizáciu takejto infraštruktúry stanovili ako svoj hlavný strategický ciel'. Aké technológie zvolili, a aký je súčasný stav využívania týchto technológií v Slovenskej republike, bude témou článku v nasledujúcom čísle časopisu. 


\section{Literatúra}

[1] Národná rada SR. Zákon o elektronických komunikáciách. 2003. [online]. TÚ SR, 2003. [cit. 2007-11-18]. Dostupné na: <http://www.teleoff.gov.sk/ sk/zakon.html>

[2] HRDINA, M.,VÚS. Zabezpečenie informačno-komunikačnej infraštruktúry na rozvoj služieb informačnej spoločnosti. 2004. [online]. Výskumný ústav dopravný, Žilina, 2004. [cit. 2007-11-20]. Dostupné na: <www.telecom.gov.sk/ index/open_file .php?file=telekom/Strategia/Vyskum/2004/zs127_2004.pdf $>$

[3] VÚS. Trendy v prístupových sietach. 2004. [online]. Výskumný ústav spojov, n.o, Banská Bystrica, 2004. [cit. 2007-11-20]. Dostupné na: <http://www.vus.sk/ broadband/nbbs/zs316_2004.pdf>

\section{Grantová podpora}

Článok je súčast'ou riešenia úlohy Zvýšenie atraktívnosti vysokej školy prostredníctvom marketingovej komunikácie vzdelávacej inštitúcie - KEGA 3/5030/07. 